\title{
STARTING A SOBER DORM: YEAR ONE CHALLENGES, SUCCESSES AND LESSONS LEARNED
} SIERRA CASTEDO*, JOHN HARRIS

*SCASTEDO@AUSTIN.UTEXAS.EDU; THE CENTER FOR STUDENTS IN RECOVERY AT THE UNIVERSITY OF TEXAS AT AUSTIN, 2109 SAN JACINTO BLVD, E8000 BEL 222, AUSTIN, TX 78712

To cite this article: Castedo, S. \& Harris, J. (2018). Starting a Sober Dorm: Year One Challenges, Successes and Lessons Learned. Journal of Recovery Science, 1(2), c13. https://doi.org/10.31886/jors.12.2018.36

To link to this article: https://doi.org/10.31886/jors.12.2018.36

\section{ABSTRACT}

This presentation is an examination of the pilot year of the Healthy Lifestyles Living Learning Community (HL LLC) substance-free housing option for incoming first year students sponsored by The Center for Students in Recovery at The University of Texas at Austin. Presenters will contextualize the history and unfulfilled need for recovery and sober student housing on the UT Austin campus, and will explore the development and implementation of a sober dorm from inception through the end of year one. Attendees will hear a candid assessment of expectations versus realities across multiple domains, including: the application process; selection of an initial cohort; the design and implementation of programming; the challenges of group cohesion and resident assistant empowerment; budget constraints; overall lessons learned; and considerations moving into year two.

\section{WHERE DO WE COME FROM, WHERE ARE WE NOW, AND WHERE ARE WE GOING? THE EVOLUTION OF COLLEGIATE RECOVERY SCIENCE}

\author{
ROBERT D. ASHFORD*, AUSTIN M. BROWN, THOMAS KIMBALL \\ *RASHFORD@MAIL.USCIENCES.EDU; UNIVERSITY OF THE SCIENCES SUBSTANCE USE DISORDERS INSTITUTE,
} 2111 MELVIN ST PHILADELPHIA PA 19131

To cite this article: Ashford, R. D., Brown, A. M., \& Kimball, T. (2018). Where do we come from, where are we now, and where are we going? The Evolution of Collegiate Recovery Science. Journal of Recovery Science, 1(2), c13. https://doi.org/10.31886/jors.12.2018.37

To link to this article: https://doi.org/10.31886/jors.12.2018.37

\section{ABSTRACT}

Attendees will be provided with a brief history/timeline of collegiate recovery as a field, through the lens of research (with a focus on the explosive growth in knowledge in the last decade). This initial presentation will be followed by a synopsis of the current state of collegiate recovery science, focusing on recent studies in the field (CRP alumni survey; meta-reviews; and any large impact studies published in the last year up to month of the conference). The session will end with a presentation on the directions for the future, making clear calls that not only does the research need to continue and in what suggested ways, but also serving to inspire students to engage in the process as they are our best hope to continue the work in innovative ways we haven't thought of. The current landscape of collegiate recovery research and recovery science overall. Additionally, attendees will be able to describe future directions for this type of inquiry.

All authors approve this manuscript and the original submission. The authors report no conflicts of interest. This work is licensed under the CC-BY license. 